\title{
Mulheres sem História
}

\section{Maria Odila Leite da Silva Dias}

Departamento de História da FFLCH da Universidade de São Paulo

“... Estas figuras que tanto antes do seu nascimento ainda não estavam retratadas nas Escrituras (porque ainda não havia Escrituras), depois que as houve, que foi sucessivamente em muitos séculos, com a mesma sucessão se foram estampando relas, posto que com sombras escuras e cores pouco vivas porque estava ainda muito longe a vida de que haviam de receber a luz..."(1)

A urbanização incipiente da cidade de São Paulo, a partir do último quartel do século XVIII até as vésperas da Abolição, envolvia uma população majoritariamente feminina e, no entanto, poucas mulheres aparecem nas histórias da cidade. Face à consolidação da economia de exportação, a urbanização era processo secundário e marginal, sintoma de pobreza e de inchação, mais do que de crescimento ou prosperidade econômica. Não admira muito o preconceituoso das fontes relativas ao espaço urbano, onde proliferava a pobreza e certa autonomia dos desqualificados sociais bastante incômoda para as autoridades. Era justamente este o espaço social das mulheres pobres, livres, forras e escravas e o palco de improvisação de sua sobrevivência precária. Circulavam pelas fontes públicas, tanques, lavadouros, pontes, ruas e praças da cidade, onde era jogado o lixo das casas e o mato crescia a ponto de ocultar escravos fugidos:

(1) '- Antonio Vieira, Sermões (rèprodução fac-similar da edição de 1692). São Paulo, Ed: Anchietana S.A., 1944, v. 9, p. 156 (do nascimento da mãe de Deus). 
o seu espaço social era justamente o ponto de interseção onde se alternavam e se sobrepunham a área de convívio das vizinhanças e dos forasteiros; a do fisco municipal e do pequeno comércio clandestino; as fímbrias da escravidão e do trabalho livre, o espaço do trabalho doméstico e de sua extensão ou comercialização pelas ruas... Sob o pano de fundo destas formas sociais transitórias é que se articulam papéis femininos propriamente históricos, de improvisação, mudança e vir a ser, dificilmente adaptáveis aos padrões hegemônicos de comportamento das mulheres das classes dominantes, e que pouco têm a ver com a identidade abstrata do ccnceito de "condição feminina", como se pudesse existir, universa! e fixa... Estudar papéis sociais femininos dentro de uma conjuntura sócioeconômica bem definida é um primeiro passo no sentido de devolver historicidade a valores culturais eivados de conotações ideológicas, que se têm por imutáveis e fixos.

Nas fontes escritas o historiador se depara com fragmentos de discursos de realidades diferentes, simultâneas, que se enredam e eludem umas às outras: o confronto do espaço das normas, dos papéis formais prescritos com o dia a dia de improvisação informal e aleatória. De um lado, devassas, processos e toda uma legislação repressiva que não podia ser aplicada na prática; de outro, resquícios de uma autonomia tolerada que ia aos poucos inchando o espaço urbano. É difícil e torturoso o desvendar deste quotidiano, que nem sequer corresponde ao tempo dos sinos das igrejas; impõe muitas reflexões sobre as limitações das fontes escritas.

Quase a totalidade das mulheres pobres de São Paulo neste período consiste de analfabetas e transparece dos documentos escritos de forma necessariamente tangencial e indireta. Quando dirigiam petições e requerimentos às autoridades era invariavelmente através de um procurador. Assinavam em geral os documentos com uma cruz ou "a rogo", deixando-se substituir por terceiros, o que as torna padrão integrado na imensa maioria da população, cujos depoimentos esparsos, quando tomados, foram sempre indiretos, co-optados e quando muito fielmente transcritos por um escrivão mais dotado e consciencioso... Distância social imensa que o historiador tem de enfrentar com dificuldades quase insuperáveis.

O testemunho de observadores contemporâneos, viajantes ou cronistas sobre a presença de mulheres pelas ruas da cidade constitui documento interessante, porém muito parcial. Atestam o seu vai e vem no comércio ambulante e sua presença nas igrejas, sentadas no chão, em esteiras: transmitem vislumbres da "pobreza recolhida" (2), que aparece furtiva e quer passar desapercebida; vultos escuros, enrolados em panos de baeta negra e quase nada mais acrescentam sobre suas condições de vida. Precon-

(2) - Bueno, Francisco de Assis Vieira, "A cidade de São Paulo", Revista do Centro de Sciencias, Letras e Artes de Campinas $\mathrm{n}^{\circ} 3$ (30 de abril de 1903), p. 29. 
ceitos elitistas impõem silêncio e omissão sobre onde moravam e como sobreviviam.

Naș entrelinhas da documentação oficial da Câmara ou dos ofícios diversos dos governadores abundam informações casuais, esparsas e muito frequentes. Brancas pobres, escravas e forras faziam o comércio menos considerado, que era o dos gêneros alimentícios, hortaliças, toucinino e fumo, nas ruas delimitadas pela câmara, nas casinhas da rua da Quitanda Velha, na ladeira do Carmo, chamado "o buracão", na rua do Cotovelo (1800)... (3). Entre a igreja da Misericórdia e a do Rosário, as quitandeiras espalhavam pelo chão trastes de um pequeno comércio de vintens, que foi aos poucos tomando becos e travessas, entre a rua do Rosário e a rua do Comércio: beco do inferno, da cachaça... a ponto de se queixarem dele os comerciantes da rua Direita, estabelecidos em suas lojas, reclamando principalmente da sujeira, dos mosquitos e dos maus cheiros (4).

Nas lojas, não se admitiam mulheres como balconistas e apenas uma ou outra mais remediada tinha o seu comércio estabelecido, armazem cu loja de molhados (5).

Avultava na cidade a disponibilidade de uma mão de obra feminina que os comerciantes não queriam e as raras manufaturas aproveitavam mal. Uma ou outra fábrica de tecidos distribuíam encomendas a costureiras e fiandeiras, que se alugavam por dia e trabalhavam em geral nas próprias casas. A cidade, comentava Velloso, em 1822, está sobrecarregada de mulheres pobres (6).

Roceiras e vendedoras perambulavam, continuamentc sob as vistas das autoridades locais, que viam com desconfiança a sua presença assídua nos principais pousos e pontes de acesso dos gêneros alimentícios à cidade. No pouso do Juqueri e do Barro Branco, na estrada de Atibaia, no Piques, no canto do Bexiga, nas margens do Anhangabaú, no caminho da Luz vendiam "a miúdo" frangos, ovos, farinha, queijos (7).

Algumas chegavam nos seus carros de boi a pretexto de trazerem pequenos excedentes de suas roças, na verdade, atravessando gêneros para fazer comércio clandestino e iludir ao fisco, conforme sucessivas denúncias

(3 - St. Hilaire, M. Auguste de - Voyage dans les provinces de S. Paul et S. Catherine. Paris, A. Bertrand, 1851, I, 271; Kidder, Dariel P.. Reminiscências de Viagens e Permanências no Brasil. São Paulo, Livraria Martins, s.d., p. 191.

(4) - Registro da Câmara Municipal de São Paulo, 16, 339-340; cf. Bruno, Ernani da Silva. História e Tradiçóes da cidade de São Paulo. Rio, José Olympio, 1954, I, 307.

(5)- Ewbank, Thomas. - Life in Brazil. N. York, Harper \& Bros., 1856, p. 71.

(6) - Velloso, Antonio Rodrigues de Oliveira. - Memória sobre o melhoramento da Província de São Paulo. Rio, Typ. Nacional, 1822, p. 113.

(7) - Registro, 15, 79-82; Morse, Richard M., Formação histórica de São Paulo, de comunidade à metrópole. São Paulo, 1970. 
registradas na Câmara. Outras traziam em seu "chio" pedras para obras na cidade ou lenha para consumo dos moradores. Vindo da Freguezia do $O$, chegavam pelos lados de Santa Ifigênia e dirigiam seus carros para o largo de São Bento, através das pontes do Açú e da Constituição (8).

Todo um caleidoscópio de pequenas referências esparsas, pingando em profusão das mais disparatadas fontes, atestam a sua presença ostensiva, porém de modo fragmentário, pouco deixando entrever sobre os seus modos de inserção na sociedade da época.

A documentação da Câmara municipal tem em vista a fiscalização do contrabando, a prática dos atravessadores, a vigilância sobre o comércio clandestino e as pequenas sonegadoras do fisco. Apesar disso, visitas de correição, pedidos de licença para vender e registros de avenças contam muito sobre o modo de sobreviver das mulheres pobres em São Paulo. Além dessa documentação, os recenseamentos ou "maços de população" são a fonte mais importante. Entretanto, trata-se de documentação igualmente policial e comprometida com uma política de controle social: capitães mores, chefes de ordenança, párocos procuravam "melhor civilizar e conter na obediência os moradores..." (9).

Muitas mulheres aparecem nas devassas de costumes feitas pela igreja, por ocasião da desobriga da Páscoa ou das Visitas Pastoraes, onde se inquiriam sobre concubinatos, alcoviteiras, curandeiras e feitiçaria. Ocorrências policiais, processos cíveis e criminais arrematam a descrição dos tipos de fontes mais ricas em dados sobre as condições de vida da população feminina de São Paulo. Escreve-se sem dúvida mais sobre "maus costumes" do que propriamente sobre a organização do seu quotidiano.

A partir da Independência, as fontes oficiais foram tomando consciência, de forma canhestra e preconceituosa, da presença maciça de mulheres na cidade. Quase quarenta por cento dos habitantes eram mulheres sós, chefes de fogo, muitas delas concubinas e mães solteiras. Nos anos que se seguiram, tanto se devassou de carbonários, como dos costumes sexuais das mulheres pobres (10). Em agosto de 1821 eram pedidas providências contra o hábito largamente difundido dos casamentos de uso costumeiro (11). Neste mesmo ano, as autoridades planejavam fundar uma roda de enjeitados e assumir algum plano de assistência contra crianças abandonadas... . (12).

(8) - Atas da Câmara Municipal de São Paulo, 26 (1832), p. 422.

(9) - Registro 12, 54 .

(10) - Registro 17, 52-57.

(11) - Registro 16 (1821) 213-4.

(12) - Atas, 22, 498; Mesgravis, Laima. "A assistência à infância desamparada e a Santa Casa de São Paulo: a roda dos expostos no século XIX", Rev. de História $103,1975,401$; Silva, Maria Beatriz N. da. "O problema dos expostos na Capitania de São Paulo", Rev. de História Econômica e Social, Lisboa, n⿳ 5, jan-jun. 1980, p. 95 ss. 
O fenômeno das mulheres sós não era estritamente peculiar a São Paulo, já tendo sido apontado e estudado nas vilas da mineração, em Salvador, no Rio de Janeiro (13). Era uma característica do processo de urbanização também na Europa do antigo regime (14). Várias causas e fatores contribuíam para gerar e multiplicar em São Paulo os fogos chefiados por mulheres sós, todos intrincadamente enredados na própria estrutura global da sociedade. Tratava-se, antes de tudo, de um processo avassalador de multiplicação da pobreza que acompanhava, principalmente, na cidade, o crescimento vegetativo da população, sob um pano de fundo de estagnação econômica.

Abarcava na cidade uma população feminina de tendência sedentária. Em 1804, apenas $27 \%$ das mulheres vinham de fora da cidade e em 1836 somente 7\% (15). Entretanto, existe na população feminina "natural da terra" um movimento de mudança para os bairros mais centrais da Sé, onde moravam costureiras, quitandeiras e vendeiras nascidas na Penha, em Cotia, São Bernardo, Juqueri, etc. (16).

Em São Paulo, tinham o costume sugestivo de abandonar os nomes de família e de adotar nomes próprios, a que o recenseador acrescentava às vezes um respeitoso "D.". Cerca de um terço delas, apenas, conservava sobrenomes de família, por vezes ilustres, dos mandões da terra e três quartos, a grande maioria, adotam nomes como Ana Gertrudes de Jesus, Maria da Cruz, Madalena de Jesus, Gertrudes do Espírito Santo, Joaquina Josefa da Anunciação, Maria da Paixão. Talvez porque fossem filhas ilegítimas, talvez porque vivessem em concubinato, provavelmente porque não tinham "os meios decentes de sobrevivência" impostos pelos padrões da terra, que lhes impunha um anonimato furtivo e recatado.

Uma porcentagem mínima delas possuía mais de 10 escravos:

(13) - Azevedo, Thales de. O povoamento da cidade de Salvador, S. Paulo, 1950, p. 212; Ramos, Donald, "Marriage and the family in colonial Vila Rica", Hispanic American Historical Review, 55, 1975, p . 200; Ramos, Donald "A estrutura demográfica de Vila Rica às vésperas da Inconfidência", V Anudrio do Museu dá Inconfidência, Ouro Preto, 1978, p. 41; del Nero, Iracy. Vila Rica: População (1719-1826). São Paulo, IPE, 1979, pp. 36, 116 ss. Marcilio, Maria Luiza. A cidade de São Paulo (Povoamento e População (1750-1810), São Paulo, 1968, pp. 106 e 123; Samara, Eny de Mesquita. A família na Sociedade Paulista do Século XIX (1800-1860). São Paulo, 1980 , pp. 39, 43 etc. (tese de doutoramento); Kuznetsof, Elisabeth. "The role of the female-headed household in Brazilian modernisation" (São Paulo, 1765 to 1836)", Journal of Social History, $\mathrm{n}^{\circ} 13$ (4): 588 ss, 1980.

(14) - Thompson, Roger. Women in Stuart England \& America: a comparative study. London, Routledge \& Kegan Paul, 1974, pp. 24 ss; Rowsbotham, Sheila. -Hidden from History. N. York, Pantheon Books, 1973.

(15) - Dias, Maria Odila Leite da Silva Ana Gertudes de Jesus (quotidiano $e$ poder em São Paulo no século XIX). São Paulo, Brasiliense, 1984.

(16) - Marcilio, Maria Luiza, op. cit., 164. 
em 1804, apenas 19 em 557 fogos; $3,61 \%$

em 1836, apenas 18 em 689 fogos; 3,06\%

Entre as proprietárias de poucos escravos nota-se a tendência a diminuir como se um gradativo processo de pauperização as levasse de roldão: num levantamento parcial, a título de amostragem, em 1804, eram 215 com poucos escravos para um total de 557 fogos: $38 ; 60 \%$. Em 1836, eram 189 com poucos escravos para um total de 589 fogos: $32,09 \%$. Em 1804 , cerca de $54,22 \%$ delas tinha alguma forma de auxiliares, senão escravos, pelo menos agregados: em 1836, apenas $42,38 \%$ tem auxiliares (18).

A tendência era aumentar o número de mulheres sem auxiliares, socialmente desclassificadas, pois o status social exigia um mínimo de escravos para assegurar o pão de cada dia e a "decência" dos serviçosl domésticos. Interessante é que entre as mulheres sem auxiliares aumentava constantemente a porcentagem de pardas e mulatas:

$\begin{array}{lrrrr} & 1804 & & 1836 & \\ \text { sem auxiliares } & 306 & 54,22 \% & 249 & 42,28 \% \\ \text { com auxiliares } & 255 & 54,78 \% & 340 & 57,72 \ldots\end{array}$

Entre as 340 mulheres sós, sem auxiliares, em São Paulo, em 1836 havia:

$\begin{array}{lr}\text { brancas } & 171=50,00 \% \\ \text { pardas } & 135=39,53 \% \\ \text { negras } & 27=8,14 \% \\ \text { índias } & 7=2,33 \%\end{array}$

Sem escravos, declaravam não ter meios decentes de subsistência e cerca de oitenta por cento diziam "viver de seu próprio trabalho".

Sobreviver e improvisar um ganha pão era atividade socialmente desqualificada, mormente tendo a ver com pequenas roças, animais de criação ou vendas de ambulantes. Os homens tratavam de manter empregos itinerantes, cobrindo com a aura de aventuras e façanhas longínquas o que de outro modo se assemelharia às tarefas próprias do sexo feminino ou dos ofícios aviltantes de escravos domésticos. Deste modo, o fenômeno das mulheres sós não decorreria tanto da itinerância dos homens, quanto da rígida demarcação de esferas de atividade de um sexo e de outro, agra-

(17) - Dias, Maria Odila L. da Silva op. cit.

(18) - Ibidem.

(19) - Ibidem.

(20) - Ibidem. 
vada ainda mais pelo costume dos casamentos de idades desiguais, que multiplicava viúvas moças de maridos trinta ou vinte anos mais velhos.

Uma peculiaridade bem paulista dos fogos de mulheres sós, comparado com o mesmo fenômeno em Vila Rica, é a presença de uma maioria de brancas pobres, como a sugerir um processo contínuo de mobilidade social descendente no seio das classes dominantes. Em Minas, o povoamento inicial foi feito com a ausência quase total de mulheres brancas, de modo a gerar, em fins do século XVIII, uma população urbana de mulheres forras mestiças. Em São Paulo, tanto num levantamento nos maços de 1804 , quanto no de 1836 , multiplicavam-se as brancas sem dotes, vivendo em casamentos de uso costumeiro, sucessivos concubinatos, muitas delas mães solteiras.

$$
1804
$$

$\begin{array}{lrl}\text { brancas } & 351=61,90 \% \\ \text { pardas } & 177=31,22 \% \\ \text { negras } & 39=6,88 \% \\ \text { índias } & 0 & \\ & 567 & \end{array}$

1836

$$
\begin{aligned}
333 & =58,12 \% \\
187 & =32,64 \% \\
36 & =6,28 \% \\
9 & =1,57 \% \\
565 &
\end{aligned}
$$

Não admira pois, sendo este o domínio dos papéis informais, que os contemporâneos não tivessem tido uma visão objetiva deste fenômeno incômodo de mulheres empobrecidas, a que se foi sobrepondo, depois de 1830, uma porcentagem crescente de excedentes do próprio sistema escravista, na medida em que a urbanização foi propiciando o aumento do número de negras forras.

Deduz-se das informações colhidas dos recenseamentos, uma certa tendência das mulheres sós de largarem as ocupações de artesanato e de adotarem principalmente trabalhos relativos ao pequeno comércio e à comercialização de serviços domésticos.

1804 (602 fogos de mulheres sós)

1836 (589 fogos)

$\begin{array}{lrrrrrr}\text { Primário } & & 45 & 7,48 \% & & 49 & 8,32 \% \\ \text { Secundário } & & 306 & 50,66 \% & \ldots & 195 & 33,11 \% \\ \text { Terciário } & & 302 & 38,01 \% & & 342 & 58,06 \% \\ \text { Diversos } & & 22 & 3,65 \% & & 3 & 0,51 \%\end{array}$

A vida errante de mulheres roceiras ou quitandeiras era considerada socialmente tão desclassificada que, embora de feição local muito peculiar, quase não vem documentada nos romances urbanos. Bernardo de Gui-
(21) - Ibidem.
(22) - Ibidem. 
marães, em Rosa, a enjeitada tem uma personagem secundária, Nha Tuca, ex-prostituta, velha taverneira que vivia no caminho da Penha com suas ex-escravas ganhadeiras... Trata-se de ocupações desairosas, a serem caladas, por evocar justamente o reverso dos papéis sociais normativos atribuídos às mulheres, que pressupunham hábitos de clausura, resguardo $\mathrm{e}$ distância social. Em São Paulo, em meados do século passado, várias das brincadeiras de rua dos estudantes consistia em se vestir de mulheres beatas ou caipiras, como se fosse um gênero a ser abolido, costumes atrasados a serem extirpados (23).

A prostituição parece atividade mais normativa e mais facilmente aceita do que ofícios ligados ao pequeno comércio ambulante. "Margaridas e cravinas de rótulas", nas palavras de José de Alencar, poderiam errar, como Luciola, mas não ultrapassar os padrões de uma pequena burguesia europeizada. O improvisar de pequenos ofícios múltiplos, acumulados, como o "viver de agências" e de bordados, ou de costuras e vendas são fontes de ganha-pão parcialmente omitidos na literatura erudita e também na documentação oficial, onde nos deparamos com a praxe do silêncio que resguarda contrabandos, por mais miúdos e insignificantes que fossem:

A documentação escrita, em geral, no que envolve assuntos relacionados com o sexo feminino está saturada e sobrecarregada do domínio de mitos, desfilando em poucas linhas, vários dos grandes arquétipos culturais da tradição judáica e cristã: anjos, demônios, santas matronas de vida honrada, mulheres perdidas, sem eira nem beira... E um vasto domínio que enreda a todos e não somente às fontes oficiais, pois mitos e símbolos são inerentes à linguagem e à cultura.

Entre roceiras caipiras e mulheres forras nas ruas de São Paulo no século passado, personagens reais tomavam antes uma coloração mítica do que a aura de personalidades políticas; D. Leopoldina, mulher fiel e mãe devotada se revestia do carisma dos contos populares mais presentes no imaginário feminino: mulheres santas injustiçadas, as Genovevas de Brabant, Inez de Castro, Porcinas de Bocaccio, ou Grisélidas do Trancozo... A Marquesa de Santos, figura local mais tangível, por ser senhora e grande dama poderosa, do seu sobradão na rua da Alegria número dez, também tomava feições míticas de Madalena arrependida: eleita do amor de Jesus, podia servir de intermediária na causa das sofredoras e necessitadas do bom caminho.

Já na documentação escrita, menos flúida do que a palavra oral, pairam sobre mulheres estereótipos de todos os tempos, adaptáveis a toda e qualquer conjuntura histórica. Metáforas e imagens que vem de autor em autor se repetindo pelos tempos afora: a figura da senhora bondosa,

(23) - Bruno, Ernani da Silva. História e Tradiçes, II, p. 825. Morse, Richard M. ob cit, p. 92 . 
dedicada à própria família, que é também hospitaleira, generosa e sempre acessível aos pobres necessitados, existe simultaneamente no imaginário popular e nos depoimentos dos cronistas e genealogistas das classes dominantes, como um elo que une as diferentes classes sociais no sistema escravocrata. E o culto de Santa Isabel, rainha e senhora caridosa, festejada na hagiologia erudita, nos sermões de Vieira, de Montalverne e nos contos populares em que se festeja a quitandeira pobre, mas hospitaleira, pronta a partilhar de sua pobreza com os que lhe batem à porta (24).

A literatura erudita transborda de referências a papéis femininos normativos próprios para serem pregados nos púlpitos e lidos como "exempla" para transmitir o certo, o desejável e o convencional:

..."Não direi que ela foi uma virgem célebre por sua inocência e por a santidade que glorificou os seus doze anos de solteira; não recordarei os dezoito anos, em que foi esposa e mãe; eu esquecerei toda esta série de acontecimentos memoráveis que n'esses dous importantes períodos adornaram a mulher forte..."

Ou Frei Gaspar da Madre de Deus, quando escreve sobre D. Maria I:

"...He mulher, eu confesso, porem mulher forte;

he mulher, porem varonil e escolhida por Deus,

como Deborah para redentora de Portugal" (25).

Processos administrativos, judiciais ou da polícia vem sobrecarregados de juizos de valor e de referências genéricas: "mulher vagabunda", "desordeiras", "turbulentas", "depravadas"; de "má fama", "cometeu ruindades", "foi falsa", "prendeu-se por acusação de andar amancebada"... (26).

Existe uma tradição misógina, fortemente entranhada, tanto na literatura erudita quanto nos contos populares portugueses, a partir de um manancial comum, os autos jesuíticos do século XVI, que penetrou na colonia e se perpetuou nas festas, cantos e costumes tradicionais. C. R. Boxer estudou este fenômeno característico das fontes primárias do Império colonial português (27).

O assunto não se esgota ao nível das fontes oficiais e dos testemunhos literários. Vários historiadores revelam a mesma incapacidade de tratar

(24) - Xidieh, Oswaldo Elias. - Narrativas pias populares. S. Paulo, 1967, pp. 40 e 44 .

(25) - Vieira, Antonio. Sermões; Montalverne, Francisco. Obras Oratórias, Rio, Garnier, s.d., II, p. 192 (panegírico de S. Rosa de Viterbo); Taunay, Aff. "Frei Gaspar da Madre de Deus", Rev. do Instituto Hist. e Geográfico de S. Paulo, XXI pp. 194-5.

(26) - Documentos Interessantes, v. 20 , p. 30; v. 46, pp. 262, 357; v. 64, pp. 102 e 151 .

(27) - Boxer, Charles R. Mary and Misogyny (Women in Iberian Expansion overseas 1415-1815). London, Duckworth, 1975. 
da participação de mulheres no processo de formação da sociedade brasileira. Perderam-se em juizos de valor e não conseguiram se desfazer de idealidades e estereótipos, o que os impediu de ver com maior clareza o contexto histórico de que tratavam. Paulo Prado, em Retrato do Brasil, refere-se às índias como a máquinas de gozo e trabalho, no agreste gineceu colonial e à passividade infantil das negras africanas (28); o próprio Gilberto Freire, estudioso dos costumes e do quotidiano, refere-se à mulher branca como a uma serva do homem e boneca de carne do marido (29).

Entre os cientistas sociais existe a tendência a definir o domínio do feminino como o reverso ou a alteridade ideal, o outro de úma cultura propriamente masculina (30). Nos próprios documentos, símbolos e metáforas escondem informações mais objetivas; imagens genéricas, depreciativas, recobrem alusões às escravas, forras e brancas pobres: critérios próprios do maniqueismo da Contra Reforma, com nuanças clássicas, que se referem ao corpo da mulher como a um objeto de conquista e de prazer sexual. Na historiografia, as mulheres tem a individualidade de personagens históricas. São forças misteriosas, desconhecidas, às vezes perigosas .

Nos cronistas e genealogistas do século XVIII, frequentemente a preocupação de construir uma racionalidade mais sistemática associada a um reformismo ardoroso, impediu-os de descrever costumes do dia a dia sem toda uma coloração normativa contra as "paixões instintivas do primitivismo feminino". Na literatura burguesa dos romances urbanos do século XIX estão sempre presentes as tensões entre o mundo feminino de forças vitalistas, do coração, do instinto, da continuidade biolágica e do encadear das gerações, contra a razão, a história, domínio propriamente dos homens. Para Machado de Assis, em Iaiá Garcia, é o confronto da natureza biológica, domínio da mulher e a natureza social, ou capacidade do homem de superar a própria espécie. Sempre é mais forte $o$ ideal feminino abstrato do que a individualidade das personagens: Fidelia vive em si o conflito do indivíduo e da espécie... Nas personagens femininas aparece, antes de tudo, a força dos instintos, o ciclo biológico e vitalista do eterno renascer, como o "uroborus" do culto da Grande Mãe (31).

Por outro lado, mesmo nos trabalhos que procuram analisar de um prisma mais objetivo o domínio do feminino, persiste a sombra do simbó167-8.

(28) - Prado, Paulo. - Província \& Nação (Retrato do Brasil), Rio; 1972; p. 94 .

(29) - Freyre, Gilberto. - Sobrados e Mocambos, Rio, J. Olympio, 1968, I,

(30) - Wolff, Kurt H., org. Georg Simmel: a collection of Essays, Columbus, Ohio State Univ. Press, 1959.

(31) - Machado de Assis, Obra Completa (Coutinho, Afrânio, org.) Rio, Aguilar, 1959, I, pp. 321 e 764; II, 1108; Neumann, Erich. The Great Mother. Londres, 1955. 
lico e das alegorias, sob a forma do conceito de "condição feminina" e certa insistência nos mitos da mulher, que pertencem ao campo da erudição, das tradições, do literário e se alimentam uns aos outros num círculo vicioso que não se rompe, justamente por faltar a vinculação a um contexto histórico específico; condição sine qua non para reconstruir a historicidade dos papéis femininos, passo importante para catarsis do conteúdo ideológico é mostrar as mulheres como seres sociais, que integram sistemas de poder, redes de dominação e laços de vizinhança. O processo propriamente histórico de suas vidas em sociedade tem bem mais a ver com um contínuo improvisar de papéis informais, mudança, vir a ser, do que com mitos e normas culturais. E preciso estudar os espaços femininos conquistados e não os prescritos, porisso em grande parte calados ou omitidos "nos documentos escritos. Os papéis propriamente históricos das mulheres podem ser captados de preferência nas tensões sociais, mediações, intermediações: nas relações propriamente sociais, que integram mulheres, história, processo social e que os historiadores podem resgatar das entrelinhas, das fissuras e do implícito nos documentos escritos. Porisso, requer uma leitura paciente, um desvendar criterioso de informações omissas ou muito esparsas, casuais, esquecidas do contexto ou da intencionalidade formal do documento.

Em 15 de setembro de 1834 foi presa no juizado do Braz, uma mulher parda, Domitildes de Trindade, que vagava pelas ruas sem passaporte, sem licença para esmolar, com um filho nos braços. "Foi interrogada; manifestou tais contradicões que parecem contínuo delírio; porisso a mandei expulsar para fora deste distrito..." (32). Processos judiciais e inquéritos policiais constituem terreno rico e fascinante para a crítica do historiador, pois oferecem todo um manancial de dados preciosos embora bastante dispersos: é o caso de uma devassa sobre o corpo de uma negra, Catarina Lopes, que foi encontrada morta no Tamanduateí, em janeiro de 1821 (33)... . Ou um simples atestado de óbito, que diz muito sobre laços de vizinhança entre mulheres pobres da cidade de Sã̀o Paulo: $\ldots$ "Aos 25 de fevereiro de 1844, faleceo Rosa Maria das Dores, forasteira, que senão sabe de onde é natural e nem se he casada ou solteira..." (34).. Informações aparentemente soltas e fragmentadas vạ̃o aos poucos recompondo um processo amplo de pauperização, que envolve e enreda os extremos mais despojados da grande cadeia de seres, que simboliza o nexo hierárquico e paternalista da sociedade escravocrata. São vislumbres de uma imensidão, retalhos de uma colcha por fazer, relances de uma inserção possível num vasto sistema de vizinhança; vislumbres de situações de vida num sistema amplo de relações de poder a ser recons-

(32) - Arquivo do Estado, Ofícios Diversos, 0870-c. 75-PO 3-d01.

(33) - Atas da Câmara, 22, 433 e 23, 16.

(34) - Arquivo da Cúria Metropolitana de São Paulo, Livro de Obitos da Sé (1830-1844). 
truido, envolvendo informações sobre cor, ocupação, sexo, idade, numa conjuntura histórica específica mais ampla, por desbravar. Frequientemente a leitura do historiador tem de ser feita à margem do "corpus" central dos documentos, senão mesmo nas entrelinhas do implícito ou omitido: é o caso das personagens mais secundárias e marginais de testamentos, justamente onde ocorrem pequenas lembranças fortuitas de última hora, evocando as primas ou as sobrinhas pobres, agregadas ou escravas "companheiras" do convívio doméstico quotidiano, as quais são legados pequenos quinhões simbólicos, com muitas alusões às relações próprias e específicas da organização do trabalho doméstico.

Em diferentes tipos de processos jurídicos, as informações vêm escondidas no rol das testemunhas: é o caso dos processos de divórcio, onde desfilam inesperadamente dados importantes sobre o nexo social de vizinhança das mulheres pobres dos arredores de São Paulo. Em 1834, Francisca Maria, parda, costureira, com 25 anos, morava na Freguezia de Nossa Senhora da Boa Viagem embora tivesse nascido na Sé e vivesse de suas "lavouras e costuras". (35); vem depor o que sabe "de ouvir dizer" das relações de sua vizinha com o marido, que a abandonou. Da mesma maneira, num processo de 1836, depõem costureiras de Atibaia: Maria Gertrudes, preta forra, casada, de 21 anos e Manoela do Espírito Santo, viúva, de 23 anos. (36).

Mulheres pobres, socialmente desqualificadas pertencem ao domínio dos espaços e papéis informais, improvisados, sintomas de necessidades novas e de mudanças estruturais. Não admira que sejam parcamente documentados nas fontes oficiais, que registram de preferência papéis prescritos e valores normativos, próprios do sistema de controle e manutenção da ordem social estabelecida.

Se os papéis informais são dificilmente captados por antropólogos menos avisados, em suas perquisas de campo (37), quanto mais não o são para historiadores limitados às fontes escritas! E preciso estar alertos para o conteúdo implícito nas entrelinhas dos documentos; saber onde buscar e como olhar... a fim de descortinar e resgatar dos documentos o quotidiano ao nível da organização domiciliar, familiar, das parentelas e vizinhanças. O quotidiano constitui terreno difícil, onde a historiografia

(35) - Arquivo da Cúria, Processos de Divórcio, estante 15, gaveta 27, n. 357.

(36) - Ibidem, $\mathrm{n}^{\circ} 365$.

(37) Murphy, Yolanda \& Robert. Women of the Forest. N. York, 1974; Friedl, Ernestine. "The position of Women: appearance and reality", Anthropological Quarterly, v. 40, pp. 95 ss; Riegelhaupt, Joyce F., "Saloio Women: an analysis of formal and informal political roles of Portuguese Peasant Women", Anthropological Quart., 40, p. 109; Chinas, Beverley. The Isthmus Zapotecs: Women's role in cultural context, N. York, 1973 . 
penetra esporadicamente com resultados brilhantes, porém sempre com enormes dificuldades de docúmentação (38).

Não são caminhos trilháveis por historiadores preocupados com métodos que pressupõem equilíbrio, funcionalidade, estabilidade, conservação e "status quo"; estes, voluntariamente ou não, vem se enredados nos conteúdos formais e normativos das fontes - leis, valores, ensinamentos, dados que veiculam o dever ser, sistemas ideológicos, de moral, que servem como instrumentos de controle e de manutenção da ordem social.

A partir destes parâmetros, tendem fatalmente alguns historiadores a interpretar papéis informais não como necessários, mas como atípicos ou patológicos e não como sintomas de mudanças da ordem social prescrita. Seria, por exemplo, o caso do predomínio nas cidades de fogos chefiados por mulheres sós, que alguns historiadores veriam, menos como uma organização de sobrevivência ditada por circunstâncias novas, do que como sintomas de anomia e de desorganização familiar.

Estas mulheres não estão integradas nas instituições do poder: não são assalariadas, não tem posses, nem propriedades; não gozam de direitos civis nem tem acesso à cidadania polîtica. Nem porisso deixam de ter a sua organização familiar e de sobrevivência e estruturas próprias, de convívio comunitário.

Judith Allen, num estudo sobre papéis informais das mulheres Igbo, da Nigéria, fez um trabalho interessante sobre a cegueira ideológica dos funcionários britânicos e suas reformas administrativas (39). Formados nos "mores" da Inglaterra vitoriana, estudaram as organizações politicas locais tendo em vista a sua integração na nova administração colonial que vinham instaurar. Reconhederam logo os papéís de liderança hierárquica dos homens e de imediato procuraram reconhecer e aproveitá-los nos quadros da nova administração local. Passou-lhes inteiramente desapercebida a organização política paralela e complementar das mulheres Igbo que tinham uma liderança política própria, costumavam reunir-se periodicamente na praça pública de suas aldeias onde tomavam as decisões e controlavam o comércio local, que era a sua esfera própria de atuação na comunidade. Ocasionalmente, investiam contra os homens, em rituais de represália tradicionais, aceitos pelos costumes locais, que os funcionários britânicos procuraram reprimir com violência policial, como explosões intempestivas de desordem, turbulência e bebedeira!

(38) - Ladurie, Emmanuel Leroy. - Montaillou. Gallimard, 1975; Genovese, Eugene D. Roll, Jordan, Roll. N. York, Pantheon Book, 1975; Thompson, E.P. The making of the English Working Class. Londres, 1973; Hufton, Olwen. The poor in 18th Century France. Oxford, Clarendon Press, 1976.

(39) - Allen, Judith. - "Sitting on a Man: colonialism and the lost political institutions of Igbo Women", Canadian Journal of African Studies, VI, (2): 165-181, 1976. 
Papéis informais embora muito importantes no processo concreto da vida quotidiana não tem um reconhecimento institucional, sendo em geral socialmente pouco valorizados. A tensão entre quotidiano e poder merece trabalho e reflexão por parte de historiadores dependentes das fontes escritas, pois a esfera do informal e do dia a dia não está integrada nos domínios do conhecimento e da erudição.

$\mathrm{Na}$ sociedade escravistä do Brasil colonial e do Império o ofício de provedor do sustento de sua casa era desairoso para homens que não queriam rebaixar-se, quando não tinham escravos, a exercer ofícios aviltantes como o cuidar das roças, dos animais domésticos ou vender pequenos excedentess, Estruturalmente marginalizado da organização econômica da colônia, o domínio do consumo permaneceu ambíguo, secundário e difícil, adaptando-se mal ao emprego da mão de obra escrava e saturado de preconceitos como ocupação vil e anti-econômica (40).

$\mathrm{Na}$ tradição oral e no dia a dia concreto e real, eram as mulheres pobres que assumiam estes ofícios necessários e socialmente desqualificados. E no entanto com enorme dificuldade que se destrincham dos documentos referencias ao seu trabalho quotidiano de provedora da própria subsistência.

Estes papéis informais, improvisados tem um sentido importante na desmitificação do tão discutido sistema patriarcal brasileiro. Por tradição e costume a divisão tradicional de funções e de tarefas entre os sexos era rigidamente à parte, estabelecendo-se esferas de atuação complementares, nitidamente separadas. A dedicação e devoção das mulheres, sua capacidade de sustentar seus senhores ou companheiros são os predicados femininos mais divulgados nos contos populares (41). Na realidade a ausência do homem ou a sua presença intermitente impunha com certa frequência não tanto a divisão como a alternância ou troca de tarefas: assumir papéis masculinos não era muito excepcional (42).

Vale enfatizar que na sociedade escravista e de economia de exportação, o consumo, o doméstico, a subsistência era domínio marginal de menosprezo social, destituído de valor econômico e normalmente delegado às mulheres.

Autoridades judiciais parecem dar como norma o papel feminino de provedoras ou de arrimo de famílias e muitas vezes recusam requerimentos pautados em papéis normativos, de órfã̃s desvalidas e de viúvas desamparadas: Em 1810, Francisca das Chagas reclamava do recrutamento de

(40) - Holanda, Sergio Buarque de. - Raízes do Brasil. Rio, 1973.

(41) - Cascudo, Luis da Câmara. Cinco Livros do Povo. Rio, José Olympio, 1953; Almeida, Aluísio de. "142 histórias brasileiras", Rev. do Arquivo Municipal, 144, 951, 163 ss; Idem, "Contos populares em São Paulo", Rev. do Arquivo Municipal, 188,91 .

(42) - Dias, Maria Odila L. Silva ob. cit. 
seu filho alfaiate, que, segundo ela, era o único arrimo de sua pobreza. O juiz indeferiu-lhe o pedido, alegando saber que: ... "vive a Suplicante de suas agências e não dos serviços de seu filho Gonçalo Silva, pois na verdade é a Suplicante trabalhadora e ativa e com uma escrava que tem de nome Joana, faz continuamente quitandas em que ganha para viver com fartura competente a seu estado" (43).

As relações domésticas de produção também têm a sua história, não se limitando à esfera do atemporal e do privado: afetadas pela crise do artesanato local em São Paulo, que se faz sentir a partir de 1810, situamse bem nas fímbrias de penetração do capitalismo industrial e do seu impacto sobre o meio social dominado pelo escravismo.

Reconstruir a organização de sobrevivência das mulheres pobres significa integrá-las na história do desemprego estrutural, fenômeno amplo e bem conhecido, que afeta de modo específico a força de trabalho feminina (44): o estudo de formas de trabalho flutuante, e temporário, mais de trabalhadoras autônomas do que de assalariadas, pressupõe antes o estudo de uma organização de sobrevivência, do que de produção ou de poupança... Integrá-las na história de sua época é restituir a memória social de um fenômeno que se mantém vivo e presente na sociedade brasileira contemporânea (45).

(43) - Arquivo do Estado, Requerimentos n. 341, cx. 93, pasta 2, doc. 74 ( 5 de outubro de 1810 ).

(44) - Hahner, June E. - "Women and work in Brazil 1850-1920", in: Alden, D. \& Dean, W., orgs., Essays concerning the socio-economic history of Brazil and Portuguese India. Gainesville, 1977, p. 87; Miranda, Glaura Vasques, "Women's labor force participation in a developing society: the case of Brazil", Signs, v. 3, (1): 261 ss; Madeira, Felicia R. \& Singer, Paul. Estrutura do emprego e trabalho feminino. São Paulo, Cebrap. 1973 (Caderno 13).

(45) - Boserup, Esther. Women's role in Economic Development. N. York, St. Martin's Press, 1970. 